SANDIA REPORT SANO22-8204 • Unininited Release - Uc 25

Printed February 1982

\title{
The Effect of Quench Rate and Refrigeration on the Mechanical Properties of HP9-4-20 Steel
}

T. F. Klimowicz, J. C. Lippold

Prepared by

Sandia National Laboratories

Albuquerque, New Mexico 87185 and Livermore, California 94550

for the United States Department of Energy

under Contract DE-AC04-76DP00789

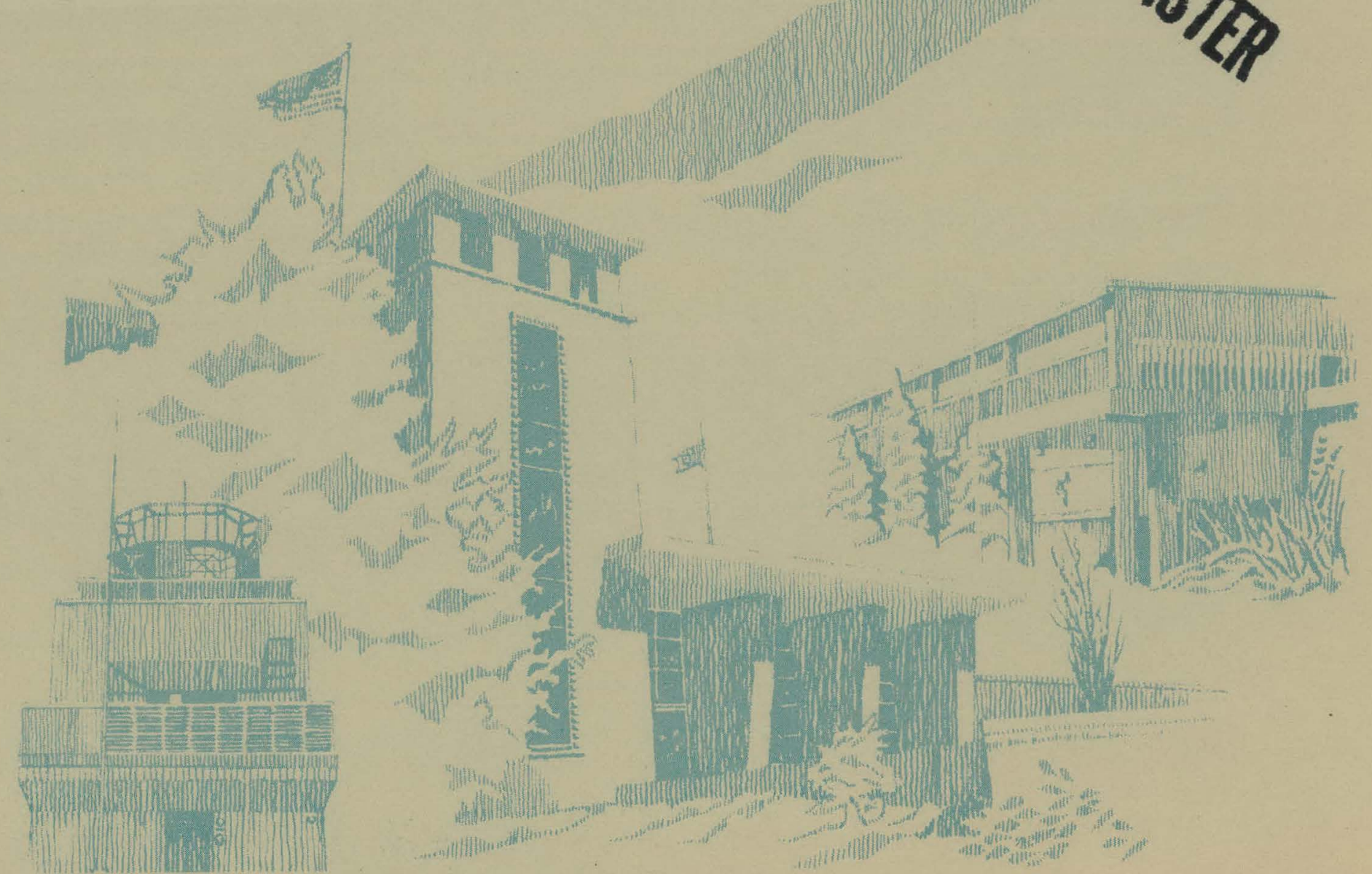




\section{DISCLAIMER}

This report was prepared as an account of work sponsored by an agency of the United States Government. Neither the United States Government nor any agency Thereof, nor any of their employees, makes any warranty, express or implied, or assumes any legal liability or responsibility for the accuracy, completeness, or usefulness of any information, apparatus, product, or process disclosed, or represents that its use would not infringe privately owned rights. Reference herein to any specific commercial product, process, or service by trade name, trademark, manufacturer, or otherwise does not necessarily constitute or imply its endorsement, recommendation, or favoring by the United States Government or any agency thereof. The views and opinions of authors expressed herein do not necessarily state or reflect those of the United States Government or any agency thereof. 


\section{DISCLAIMER}

Portions of this document may be illegible in electronic image products. Images are produced from the best available original document. 
Issued by Sandia Laboratories, operated for the United States Department of Energy by Sandia Corporation.

\section{NOTICE}

This report was prepared as an account of work sponsored by the United States Government. Neither the United States nor the United States Department of Energy, nor any of their employees, nor any of their contractors, subcontractors, or their employees, makes any warranty, express or implied, or assumes any legal liability or responsibility for the accuracy, completeness or usefulness of any information, apparatus, product or process disclosed, or represents that its use would not infringe privately owned rights. 


\section{PAGES 1 to 2 WERE INTENTIONALLY LEFT BLANK}




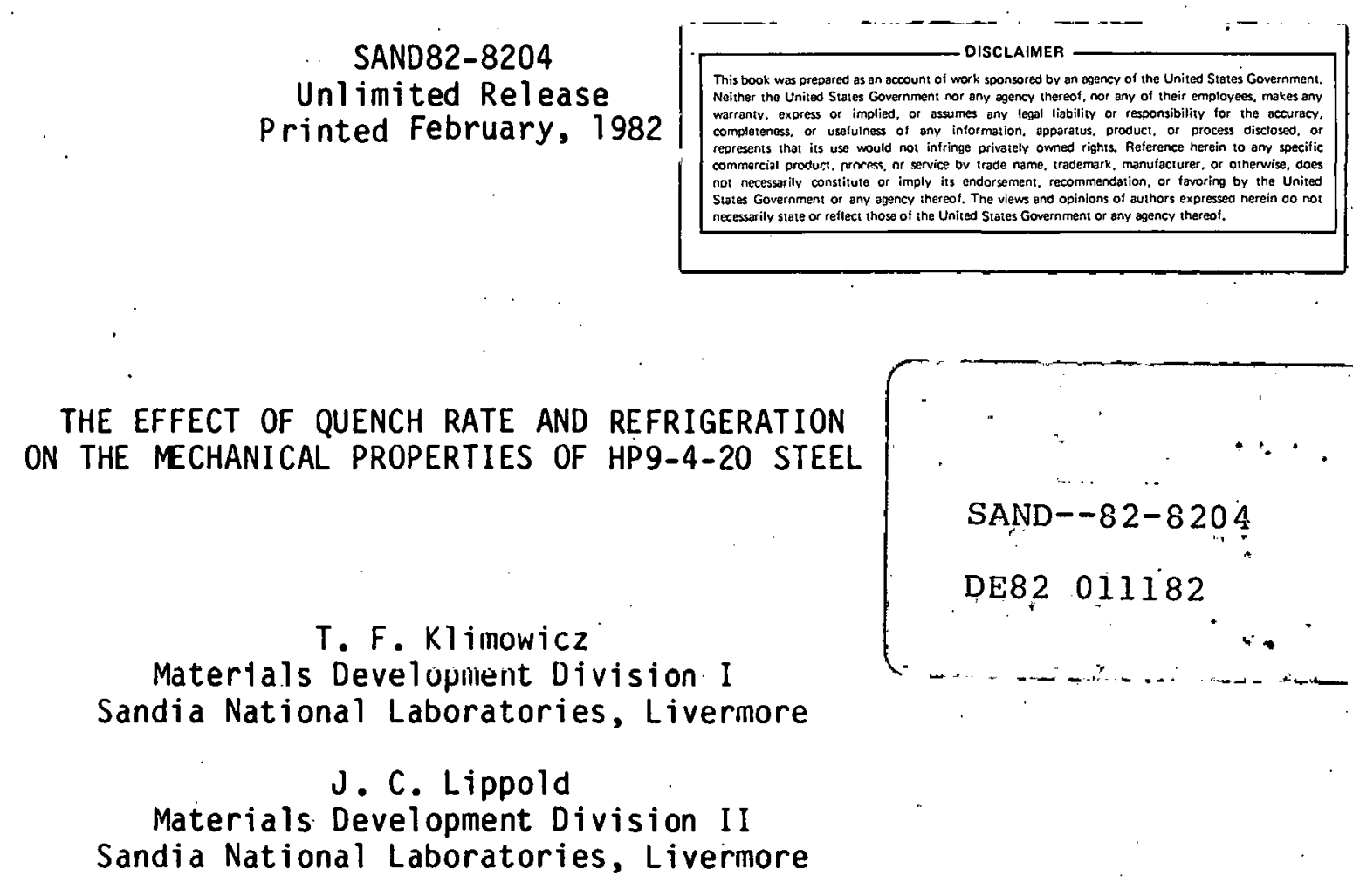

\section{ABSTRACT}

Difficulties in obtaining adequate mechanical properties in the HP9-4-20 portion of the B83 structural midcase have raised some questions concerning the effect of quench rate and post-quench refrigeration on the strength and toughness of the material. As a result, a program was initiated to determine if either of these parameters contributed to the observed degradation in properties or whether some other step in the processing history of the material was responsible. Initially, the nominal cooling rate of a full size mid-case was calculated numerically using a finite difference therinal conduction code. A series of HP9-4-20 steel samples was then processed with quench rates which bracketed this calculated cooling rate. It was found that neither quench rate nor refrigeration had a significant effect on the mechanical properties at cooling rates that might reasonably be encountered in production hardware. Consequently, it was concluded that the inadequate mechanical properties exhibited by early $B 83$ mid-case components were related to an improper tempering heat treatiment, and not an inadequate quench. 


\section{CONTENTS}

$\begin{array}{lr}\text { Introduction } & \frac{\text { Page }}{9} \\ \text { Numerical Calculations of the Quench Rate of the B83 Mid-Case } & 9 \\ \text { Experimental Procedure } & \\ \quad \text { Numerical Calculations of the Quench Rate of the B83 Mid-Case } & 9 \\ \text { Heat Treatment and Mechanical Testing } & 10 \\ \text { Results and Discussion } & 12 \\ \text { Mechanical Properties } & 12 \\ \text { Microstructure } & 12 \\ \text { Transformation Kinetics } & 13 \\ \text { Tempering Response } & 13 \\ \text { Conclusions } & 16 \\ \text { REFERENCES } & 17\end{array}$


No. Page

1. Temperature at the Center of the 883 Mid-Case
During Quenching

2. Yield Strengh vs. Cooling Rate for HP9-4-20 Steel 19

3. Charpy V-Notch Toughness vs. Cooling Rate for HP9-4-20 Steel

4. Tensile Fracture Surfaces of HP9-4-20 20

5. Charpy V-Notch Fracture Surfaces of HP9-4-20 21

6. Typical Prior Austenite Grain Structure of HP9-4-20 22

7. Martensite Lath Morphology of HP9-4-20 22

8. Isothermal Transformation Diagram for HP9-4-20 - 23

9. Continuous Cooling Transformation Diagram for HP9-4-20 23

TABLES

No. $\quad$ Page

I Chemical Composition of HP9-4-20 Plate. 11

II Mechanical Properties of HP9-4-20 as a Function of Quench Rate

III Mechanical Properties of HPg-4-20 as a Function of Tempering Temperature 


\section{ACKNOWLEDGMENTS}

The authors gratefully acknowledge Don Beard for sample preparation and heat treating, Diane Bell for the finite difference calculations, Rich Bell for Gleeble operation, Dale Boehme for X-ray analysis, Vic Ham for Mini-HIPper operation, and Don Lind for SEM analysis. 
THE EFFECT OF QUENCH RATE AND REFRIGERATION

ON THE MECHANICAL PROPERTIES OF HP9-4-20 STEEL

\section{Introduction}

In the heat treatment of martensitic steels, the quenching operation is a critical step in obtaining desired microstructures and mechanical properties. By varying the quench rate, it is possible to form a myriad of different constituents including: martensite, upper bainite, lower bainite, pearlite, proeutectoid ferrite, cementite, retained austenite, and complex mixtures of several of these constituents (which usually result in grossly different mechanical properties). With conventional "quenched and tempered" steels, the usual practice is to quench at rates sufficiently rapid to form only martensite, and then temper the high strength martensite in order to increase the toughness. At cooling rates slower than a certain "critical" cooling rate (which is a function of alloy content), the other aforementioned constituents may begin to form. The appearance of these other constituents, most notably bainite and pearlite, often is accompanied by lower tensile strength and toughness.

During the development of the manufacturing procedure for the B83 midcase, a number of mid-case components were found to have yield strength. values substantially below the specified minimum of $180 \mathrm{KSI}$. Initial speculation on the failure to meet minimum mechanical properties focused on the possibility of 1) an inadequate quenching operation, and 2) an incorrect tempering treatment. Metallographic examination of the low yield strength material, however, revealed no microstructural differences which served to isolate the cause of the low tensile properties. Consequently, this investigation was initiated to examine the effect of quench rate and refrigeration on the mechanical properties of HP9-4-20.

\section{Experimental Procedure}

Numerical Calculation of the Quench Rate of the B83 Mid-Case

As a first step in this investigation, the nominal quench profile of a full size mid-case was estimated by numerical calculation using the SAHARA finite difference thermal conduction code. The mid-case blank was modeled as a $38 \mathrm{in}$. long $\times 18$ in. 0.D. cylinder with a $0.8 \mathrm{in}$. wall thickness. Constant, temperature independent values for the thermal conductivity, "k", and the heat transfer coefficient, " $h$ " were assumed to be $18 \mathrm{Btu} / \mathrm{ft}-\mathrm{hr}{ }^{\circ} \mathrm{F}$ and $80 \mathrm{Btu} / \mathrm{hr}-\mathrm{ft}^{2}{ }^{\circ} \mathrm{F}$ respectively. This latter value for " $\mathrm{h}$ " corresponds, for steel, to a quench in oil with "moderate" agitation. With "violent" 
agitation (in oil); $h$ may be as high as 170 , and with no agitation, it may be as low as $48^{1}$. As initial conditions, the temperature of the part was set at $842^{\circ} \mathrm{C}$ (the austenitizing temperature), and the temperature of the bath at $50^{\circ} \mathrm{C}$. Cooling was assumed to occur by forced convection and the temperature of the bath was assumed to remain at $50^{\circ} \mathrm{C}$ throughout the quench. For comparative purposes, the cooling profile was also calculated for a quench in water (with no agitation) where the heat transfer

coefficient was $240 \mathrm{Btu} / \mathrm{hr}-\mathrm{ft}^{2}{ }^{\circ} \mathrm{F}$.

Within the interior of the mid-case, the temperature was calculated using the well known conduction equation:

$$
\frac{d T}{d t}=\alpha \nabla^{2} T
$$

$$
\text { where } \begin{aligned}
T & =\text { temperature } & k & =\text { thermal conductivity } \\
t & =\text { time } & \rho & =\text { density } \\
\alpha & =k / \rho C_{T} & C_{T} & =\text { heat capacity }
\end{aligned}
$$

At the steel-oil interface, cooling was assumed to occur by forced convection, and the following boundary condition was used:

$$
k \frac{d T}{d N}=h\left(T_{\text {surface }}-T_{\text {ambient }}\right)
$$

where $N$ is the direction normal to the surface.

Figure 1 shows the temperature profiles calculated for the mid-point of the wall (i.e. 19 in. from either end and 0.4 in. into the wall thickness) where the cooling rate would be the slowest. Surface temperature profiles were also calculated; but because they were virtually identical to the midthickness profiles (shifted no more than 5 seconds to the left) they are not shown.

\section{Heat Treatment and Mechanical Testing}

Tensile and Charpy V-notch blanks were thermally cycled in either a Gleeble or a Conway Pressure Systems Mini-HIPperTM to simulate the range of rates that might be experienced by the mid-case during quenching. The composition of the .56 in. plate used in this investigation is shown in Table I. 
TABLE I

CHEMICAL COMPOSITION OF HP9-4-20 (WT. PERCENT)

\begin{tabular}{ccccccccc}
\hline $\mathrm{Ni}$ & $\mathrm{Co}$ & $\mathrm{C}$ & $\mathrm{Mo}$ & $\mathrm{Cr}$ & Mn & S & $\mathrm{P}$ \\
\hline \hline 9.18 & 4.40 & .20 & 1.09 & .74 & .44 & .004 & .008 \\
\hline
\end{tabular}

Prior to the Gleeble heat treatment, the samples were normalized at $900^{\circ} \mathrm{C}$ $\left(1650^{\circ} \mathrm{F}\right)$ for 1 hour, air cooled, and then austenitized at $842^{\circ} \mathrm{C}\left(1550^{\circ} \mathrm{F}\right)$ for 1 hour and oil quenched. The samples were then rapidly heated in the Gleeble to $842^{\circ} \mathrm{C}$, soaked at temperature for 5 minutes, and then cooled at six cooling rates, namely, $15,10,5,3,1$, and $.5^{\circ} \mathrm{C} / \mathrm{sec}$. A 2 -in. jaw separation was used in order to ensure that a uniform temperature zone would exist along the specimen axis. The samples treated in the Mini-HIPper were heated to $842^{\circ} \mathrm{C}\left(1550^{\circ} \mathrm{F}\right)$ in fifteen minutes, soaked at temperature for 1 hour, and then cooled at $0.2^{\circ} \mathrm{C} / \mathrm{sec}$. The seven cooling rates used in this experiment bracketed the average cooling rate of $-4^{\circ} \mathrm{C} / \mathrm{sec}$. which was calculated using the finite difference code.

Following the thermal treatment, half the samples tested at a particular cooling rate were refrigerated for 1 hour at $-73^{\circ} \mathrm{C}\left(-100^{\circ} \mathrm{F}\right)$, in accordance with the recommended procedure for this alloy. Finally, all samples were tempered at $565^{\circ} \mathrm{C}\left(1050^{\circ} \mathrm{F}\right)$ for 4 hours prior to the final machining. I.t is important to emphasize that all samples were tempered. In this investigation, no mechanical property evaluation was done on as-quenched material.

Ambient temperature tensile properties were determined using 0.60 in. gauge length $\times 0.125$ in. diameter tensile bars (Sandia Drawing K97465). These short gauge length specimens were used in order that the entire tensile sample be within the uniform temperature zone produced during Gleeble treatment. Samples were oriented in the longitudinal direction and strained at a crosshead speed of $.02 \mathrm{in.} / \mathrm{min}$. Yield strengths were determined using the $0.2 \%$ offset method. The reported values are the average of two specimens tested per condition.

The Charpy impact specimens were oriented such that the fracture propagated in the transverse direction (the L-T orientation). The reported values are the average of at least four specimens tested per condition. All tests were performed at room temperature.

$X$-ray diffraction was used to quantitatively measure the amount of retained austenite in the as-quenched and the as-quenched and refrigerated samples. The specimens were first polished and etched in an $\mathrm{HF} / \mathrm{H}_{2} \mathrm{O}_{2}$ solution to obtain a deformation-free surface. They were then scanned in a Diano $X$-ray diffractometer using CuK $_{\alpha}$ radiation. The scan angle $(2 \theta)$ covered $70^{\circ}$ to $95^{\circ}$ : This range included the $(211)_{\alpha},(311)_{\gamma}$, and the $(220)_{Y}$ reflections. The details of the method used to quantify the amount of austenite have previously been described by Miller. ${ }^{2}$ 
Results and Discussion

Mechanical Properties

As can be seen in Figure 1, with an oil quench, it takes approximately $170 \mathrm{sec}$ to cool the center of the mid-case from the austenitizing temperature of $842^{\circ} \mathrm{C}\left(1550^{\circ} \mathrm{F}\right)$ to $150^{\circ} \mathrm{C}\left(150^{\circ}\right.$ below the $M_{s}$ temperature of $\left.300^{\circ} \mathrm{C}\right)$. This translates to an average cooling rate of $\sim 4^{\circ} \mathrm{C} / \mathrm{sec}$. Based on this average cooling rate, experimental rates ranging from $15^{\circ} \mathrm{C} / \mathrm{sec}$ down to $.2^{\circ} \mathrm{C} / \mathrm{sec}$ were investigated. The results of the tensile and Charpy $\mathrm{V}$-notch tests are tabulated in Table II and plotted in Figures 2 and 3 . For cooling rates down to $.5^{\circ} \mathrm{C} / \mathrm{sec}$, neither cooling rate nor refrigeration have a significant effect on mechanical properties. At the slowest cooling rate of $.2^{\circ} \mathrm{C} / \mathrm{sec}$, however, the yield strength (without refrigeration) drops to 174 KSI, which is slightly below the specified minimum of $180 \mathrm{KSI}$. However, when the specimens were refrigerated after quenching, the yield strength recovered to $184 \mathrm{KSI}$. This indicates that over the range of $15^{\circ} \mathrm{C} / \mathrm{sec}$ to $.2^{\circ} \mathrm{C} / \mathrm{sec}$, the cooling rate has no significant effect on the mechanical properties, provided that the material is properly refrigerated and tempered. Furthermore, refrigeration appears to have no significant effect at cooling rates of $.5^{\circ} \mathrm{C} / \mathrm{sec}$ or faster. It is only at the extremely slow cooling rate of $.2^{\circ} \mathrm{C} / \mathrm{sec}$ that refrigeration exhibits any beneficial effect.

The negligible effect of the cooling rate on the mechanical properties of HP9-4-20 is consistent with the retained austenite measurements shown in Table II. Even at the slowest cooling rate, the austenite content is only $\sim 3 \%$, a level that would be expected to have only a small effect on the mechanical properties. In addition, the retained austenite measurements were made on as-quenched (untempered) material and the tempering process tends to reduce the retained austenite content even further, as the austenite decomposes to form bainite. It is interesting to note that although the yield strength is lowered slightly (in the $.2^{\circ} \mathrm{C} / \mathrm{sec}$, unrefrigerated case) the ultimate strength is not degraded. This is probably a consequence of both the high work-hardening rate of the austenite, and the transformation of the retained austenite to strain induced martensite during the tensile test.

\section{Microstructure and Fractography}

Since microstructure is known to significantly influence the mechanical properties of HP9-4-20, it is not surprising that the microstructures showed no difference over the range of cooling rates investigated. Figures 4 and 5 compare the tensile and Charpy fracture surfaces for the lowest and highest cooling rates. In all cases, an identical microvoid coalescence fracture morphology can be seen. No intergranular or quasi-cleavage fracture was observed in any of the samples examined. In addition, no differences were noted in either the prior austenite grain size or the martensite lath inorphology (examples of which are shown in Figures 6 and 7). 
Transformation Kinetics

On the isothermal transformation diagram shown in Figure 8 , the start of the bainite reaction occurs at 15 minutes. Based on the computer calculated cooling rate of $4^{\circ} \mathrm{C} / \mathrm{sec}\left(\right.$ or $\left.240^{\circ} \mathrm{C} / \mathrm{min}\right)$, this indicates that there should be no bainite formation during the quenching operation. This is especially true when one considers that the transformation start and finish lines are shifted downward and to the right when comparing the isothermal to the continuous cooling transformation diagrams. 5 This suggests that during continuous cooling it would take even longer to start the bainite reaction than is indicated on the isothermal transformation diagram. However, the continuous cooling transformation (CCT) diagram shown in Figure 9 is contrary to what would normally be expected in that the bainite nose is shifted sharply to the left relative to the isothermal transformation diagram. Consequently, the CCT diagram shown in Figure 9 would predict that, during quenching, the $B 83$ mid-case would cross quite deeply into the bainite nose.

The effect of a large amount of bainite on the mechanical properties is not certain. However, the present investigation has shown that regardless of whether or not bainite is formed, cooling rates as slow as $.2^{\circ} \mathrm{C} / \mathrm{sec}$ $\left(12^{\circ} \mathrm{C} / \mathrm{min}\right)$ will produce yield strengths in excess of $180 \mathrm{KSI}$ provided the material is properly refrigerated and tempered. Further work is needed to resolve the question of bainite formation, and the discrepancy between the isothermal and continuous cooling transformation diagrams.

\section{Tempering Response}

Previous work ${ }^{6}$ on the tempering response of HP9-4-20 has shown that an excessively high tempering temperature will produce low yield strengths. Table III shows the tensile properties for material which was tempered over the range of $200^{\circ} \mathrm{C}-650^{\circ} \mathrm{C}$. As can be seen, a $4 \mathrm{hr}$. temper at $600^{\circ} \mathrm{C}\left(1112^{\circ} \mathrm{F}\right)$ will produce a yield strength of $160 \mathrm{KSI}$, while $4 \mathrm{hrs}$. at $625^{\circ} \mathrm{C}\left(1157^{\circ} \mathrm{F}\right)$ will give a yield strength of $127 \mathrm{KSI}$. Thus, it is indeed possible to produce the low yield strengths seem in the early 883 mid-case simply by overtempering.

In the present investigation, we have shown that quench rate has a negligible effect on mechanical properties at rates which might reasonably be encountered in production hardware. Consequently, we believe that the low yield strengths encountered in early mid-cases were the result of an excessive temper, and were not related to the quenching operation. 
TABLE II

MECHANICAL PROPERTIES OF HP9-4-20 AS A FUNCTION OF QUENCH RATE

\begin{tabular}{|c|c|c|c|c|c|c|}
\hline $\begin{array}{l}\text { Cooling } \\
\text { Rate } \\
{ }^{\circ} \mathrm{C} / \mathrm{sec}\end{array}$ & ${ }^{\sigma}{ }^{\prime} y_{I}$ & $\begin{array}{l}\text { OULT } \\
\text { KSI }\end{array}$ & ${ }_{\mathrm{T}}^{\mathrm{TOT}}$ & $\underset{\%}{\text { R.A. }}$ & $\begin{array}{l}\text { Cv } \\
\text { Ft. Lb. }\end{array}$ & $\begin{array}{c}\text { Retained Austenite } \\
\text { (as-quenched) } \\
\text { Vol..\% }\end{array}$ \\
\hline 15 & 182 & 198 & 17.3 & $69^{\prime}$ & $53: 6$ & 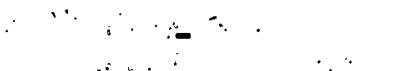 \\
\hline 10 & 185 & 199 & 15.0 & 68 & 61.3 & $-\cdots$. \\
\hline 5 & 185 & 198 & 16.4 & 70 & 58.9 & - \\
\hline 3 & 187 & 203 & $16: 2$ & 68 & 62.2 & - \\
\hline 1 & 186 & 204 & $\therefore \quad 15.1$ & 67 & 53.2 & - \\
\hline .5 & 191 & 203 & 15.6 & 68 & 61.7 & 2.1 \\
\hline .2 & 174 & 207 & $: 16: 6$ & 68 & 55.8 & 3.3 \\
\hline
\end{tabular}

Refrigerated, $-73^{\circ} \mathrm{C}, 1 \mathrm{HR}$.

\begin{tabular}{|c|c|c|c|c|c|c|}
\hline 15 & 186 & 197 & 14.6 & 68 & 56.7 & - \\
\hline 10 & $187^{\circ}$ & 199 & 15.3 & 68 & 56.2 & - \\
\hline 5 & 187 & 199 & 15.9 & 68 & 60.5 & - \\
\hline 3 & 187 & 203 & 15.0 & 67 & 60.9 & - \\
\hline 1 & 189 & 201 & 16.1 & 71 & 59.1 & - \\
\hline .5 & 189 & 200 & 13.9 & 69. & 62.5 & 1.7 \\
\hline .2 & 184 & 205 & 16.0 & 68 & 56.6 & 3.1 \\
\hline
\end{tabular}




\section{TABLE III}

MECHANICAL PROPERTIES OF HP9-4-20 AS A FUNCTION OF TEMPERING TEMPERATURE

(4 HR. TEMPER)

\begin{tabular}{cccc}
\hline $\begin{array}{c}\text { Tempering } \\
\text { Temperature } \\
{ }^{\circ} \mathrm{C}\end{array}$ & $\begin{array}{c}\sigma_{y} \\
\text { KSI }\end{array}$ & $\begin{array}{c}\sigma_{U L T} \\
\text { KSI }\end{array}$ & $\begin{array}{c}C_{v} \\
\text { Ft. Lb. }\end{array}$ \\
\hline \hline As Quenched & 180 & 238 & 33.2 \\
200 & 174 & 227 & 41.8 \\
300 & 174 & 214 & 35.8 \\
400 & 179 & 211 & 32.8 \\
500 & 189 & 214 & 41.3 \\
565 & 184 & 200 & 58.7 \\
600 & 160 & 176 & 83.8 \\
625 & 127 & 169 & 89.0 \\
650 & 113 & 181 & 61.0 \\
\hline
\end{tabular}




\section{Conclusions}

As an initial step in this investigation, the nominal cooling rate of a B83 mid-case blank quenched into oil. was: calculated by finite difference methods and found to be $\sim 4^{\circ} \mathrm{C} / \mathrm{sec}$, in the range of $842-150^{\circ} \mathrm{C}$. A series of HP9-4-20 tensile and Charpy samples was then processed with cooling rates which bracketed this calculated cooling rate. Based on the evaluation. of these samples, the following conclusions can be made:

1. Over the range from $15^{\circ} \mathrm{C} / \mathrm{sec}$ to $.2^{\circ} \mathrm{C} / \mathrm{sec}$, the cooling rate has no significant effect on the mechanical properties, provided that the material is properly refrigerated and tempered.

2. Refrigeration has no signficiant effect at cooling rates of $.5^{\circ} \mathrm{C} / \mathrm{sec}$ or faster. It is only at the extremely slow cooling rate of $.2^{\circ} \mathrm{C} / \mathrm{sec}$ that refrigeration provides any beneficial effect.

3. "The results of this investigation indicate that the inadequate tensile properties exhibited by early $B 83$ mid-cases were probably due to an excessively high tempering temperature rather than a slow cooling rate from the austenization temperature. 


\section{REFERENCES}

1. G. H. Geiger and D. R. Poirier, Transport Phenomena in Metallurgy, Addi son-Wesley Publishing Company, Reading, MA., 1973, p. 259.

2. R. L. Miller, "A Rapid X-Ray Method for the Determination of Retained Austenite," Trans. of the ASM, 57, (1964) 892.

3. R. T. Ault, Properties of Republ ic HP9-4-20 Steel, Report TR 12018-132, Republic Steel Corporation, Cleveland, Ohio, March 11, 1968.

4. D. Coutsouradis, N. Lambert, J. M. Drapier, and L. Habraken, "Microstructures and Properties of $9 \mathrm{Ni}-4 \mathrm{CO}$ High Strength Steels," Cobalt, 37, (1967) 192 .

5. R. E. Reed-Hill, Physical Metallurgy Principles, D. Van Nostrand Company, New York, 1973 p. 702.

6. T. F. Klimowicz, 8312 , memo dtd. 3/6/81, subject, Tempering Response of HP9-4-20. 


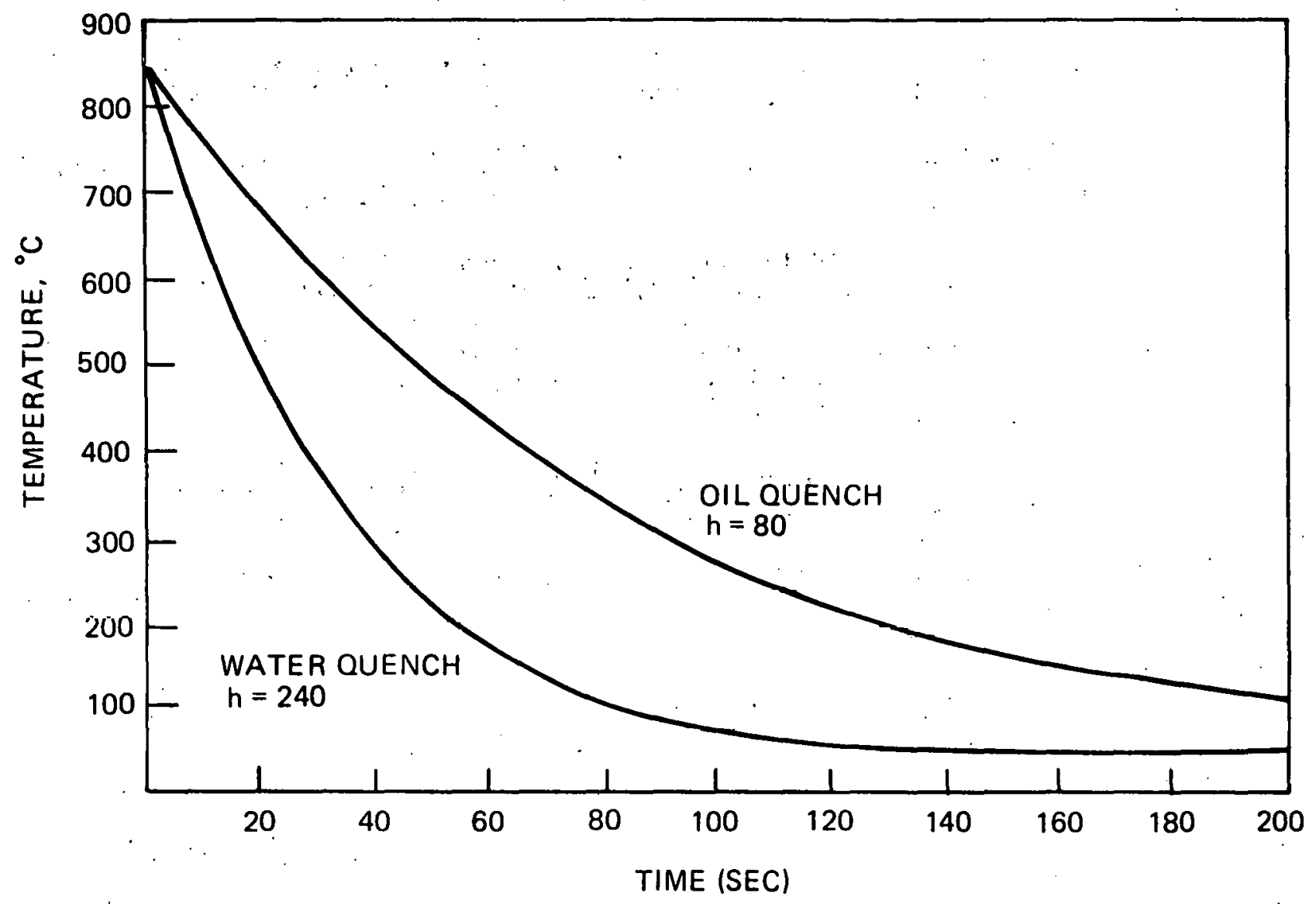

Figure 1. Temperature at the center of the $B 83$ mid-case blank during quenching in oil and water. The heat transfer coefficient, " $h$ ", (in $B t u / h r-f t^{2 \circ} \mathrm{F}$ ) is 1 isted for each quenching medium. 


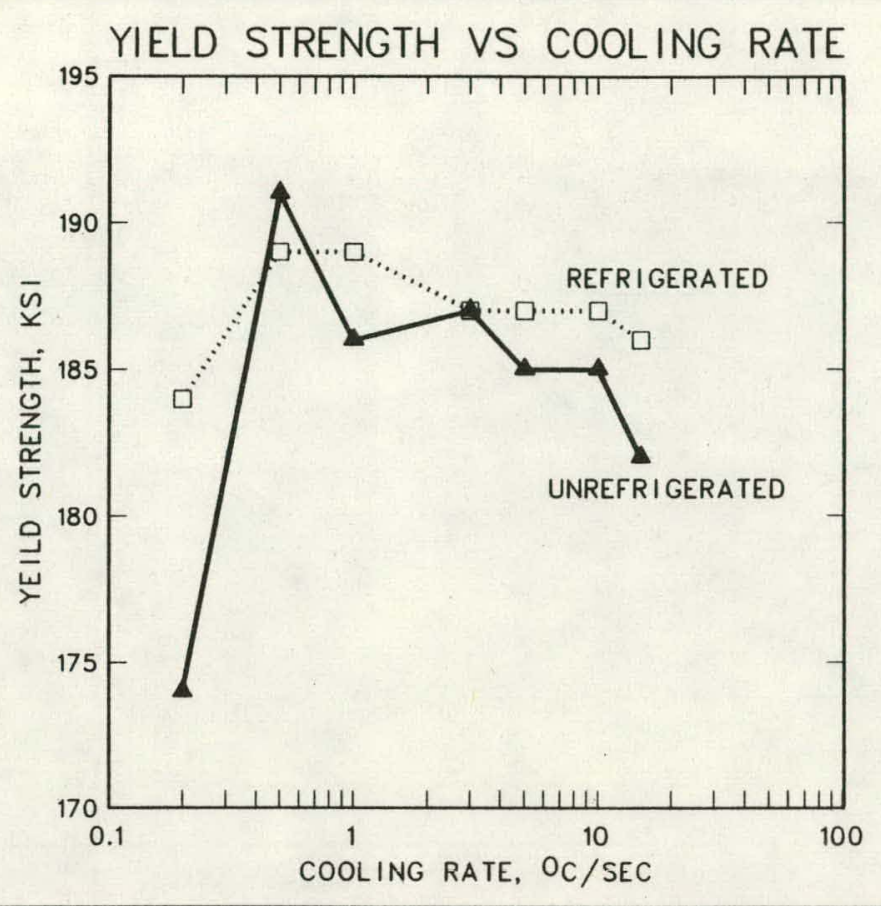

WW10778

Figure 2. Yield strength vs. cooling rate for HP9-4-20 steel.

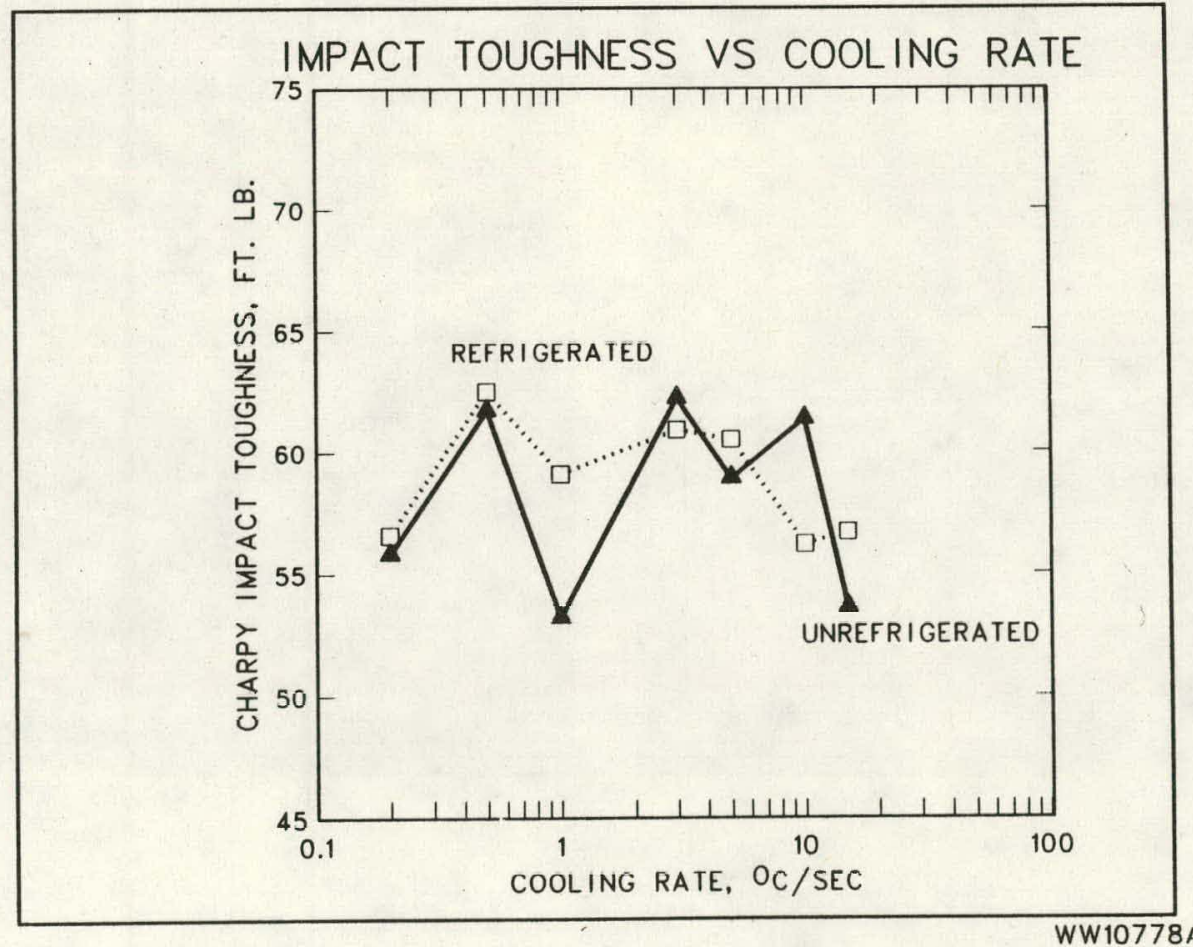

Figure 3. Charpy V-notch toughness vs. cooling rate for HP9-4-20 steel. 

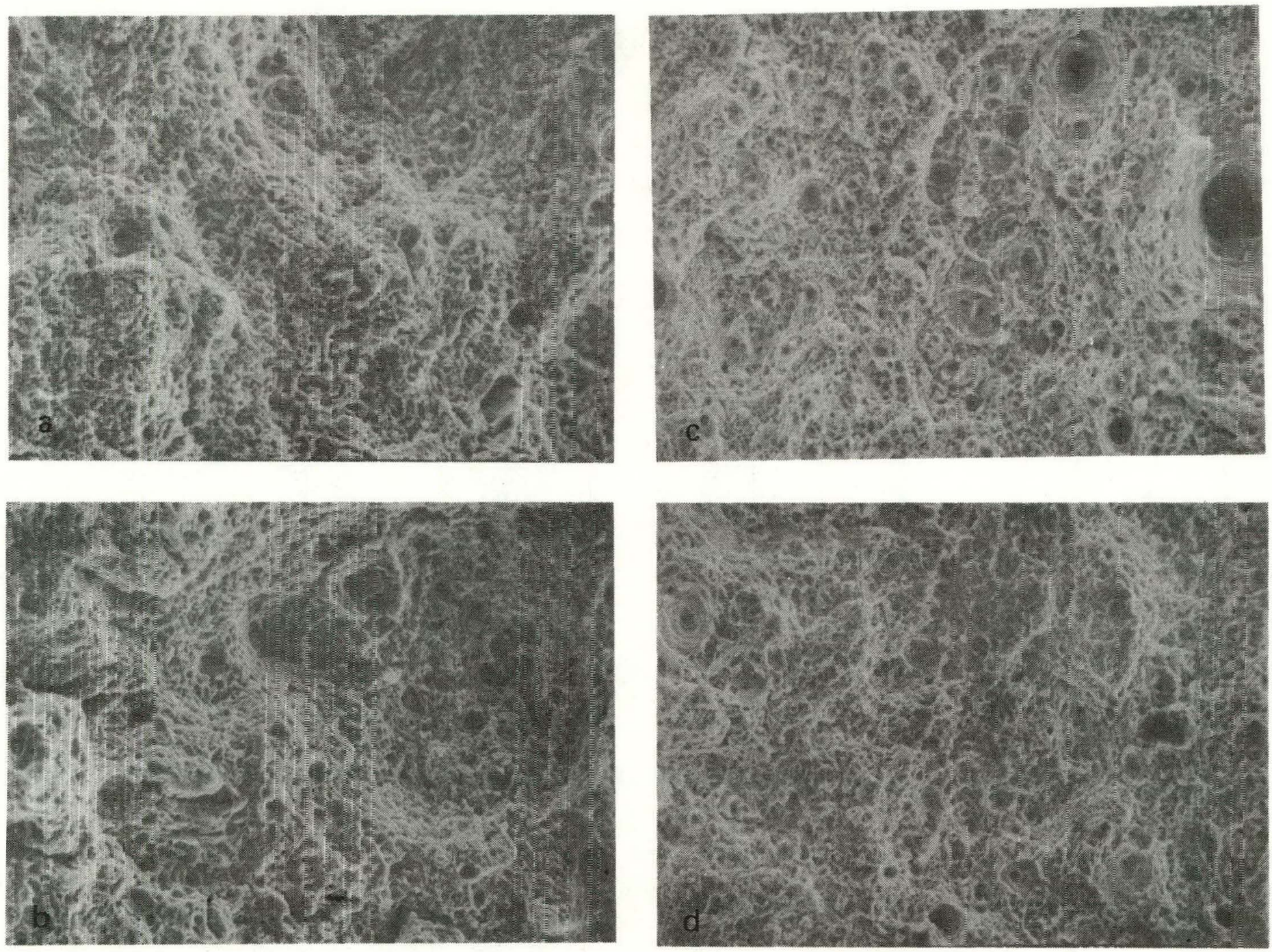

Figure 4. Tensile fracture surface of $\mathrm{HP} 9-4-20$, tempered at $565^{\circ} \mathrm{C}, 4 \mathrm{hrs}$. (a) cooled at $.2^{\circ} \mathrm{C} / \mathrm{sec}$, no refrigeration (b) $\mathrm{coc}^{7}$ ed at $.2^{\circ} \mathrm{C} / \mathrm{sec}$, with refrigeration (c) cooled at $15^{\circ} \mathrm{C} / \mathrm{sec}$, no refrigerat- on (d) cooled at $15^{\circ} \mathrm{C} / \mathrm{sec}$, with refrigeration. 

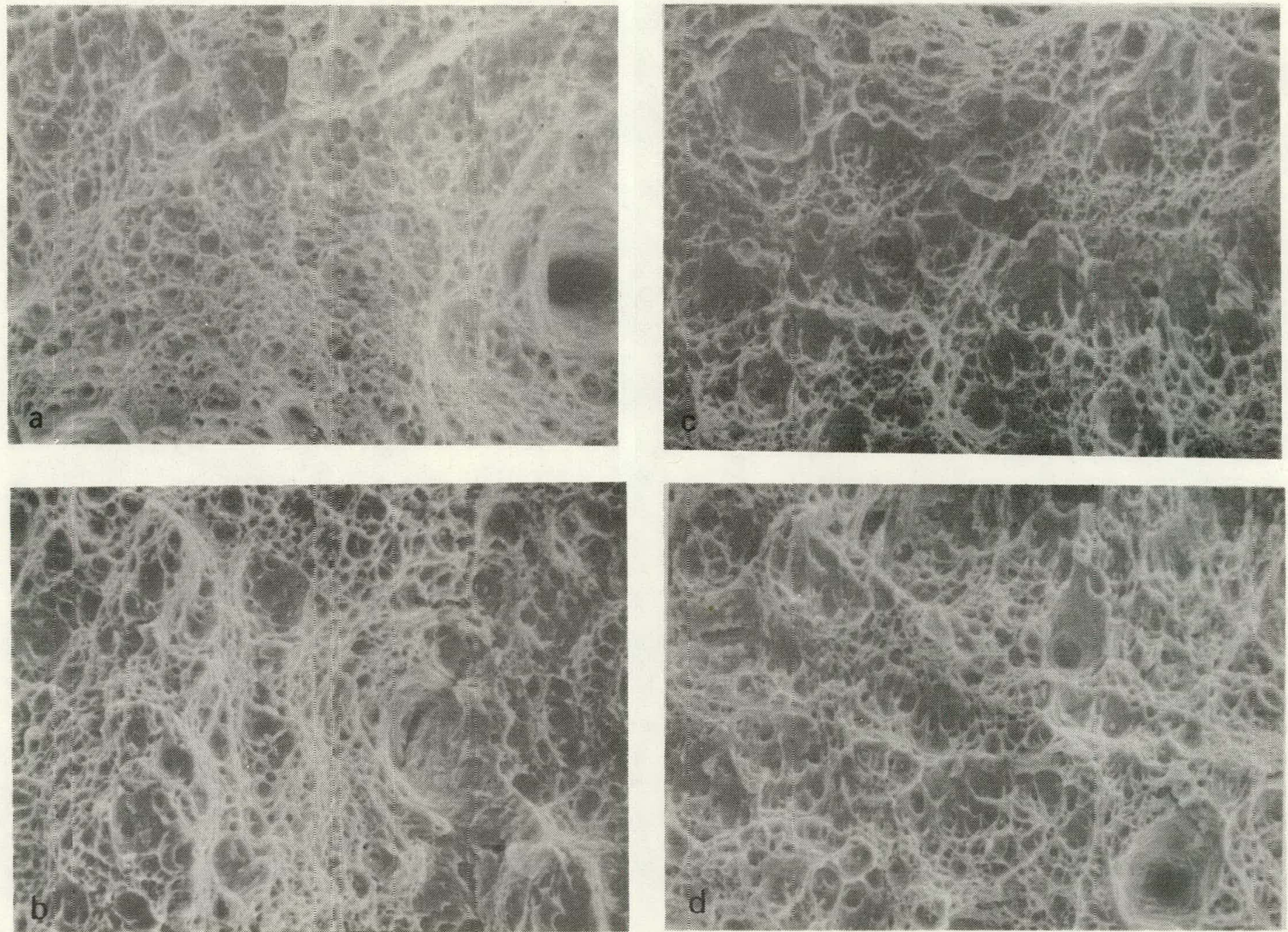

Figure 5. Charpy V-notch fracture surfaces of HP9-4-20, tempered at $565^{\circ} \mathrm{C}$, $4 \mathrm{hrs}$. a) cooled at $.2^{\circ} \mathrm{C} / \mathrm{sec}$, no refrigeration, (b) cooled at $.2^{\circ} \mathrm{C} / \mathrm{sec}$, with refricration (c) cooled at $15^{\circ} \mathrm{C} / \mathrm{sec}$, no refrigeration, (d) cooled at $15^{\circ} \mathrm{C} / \mathrm{sec}$, with refrigeration. 


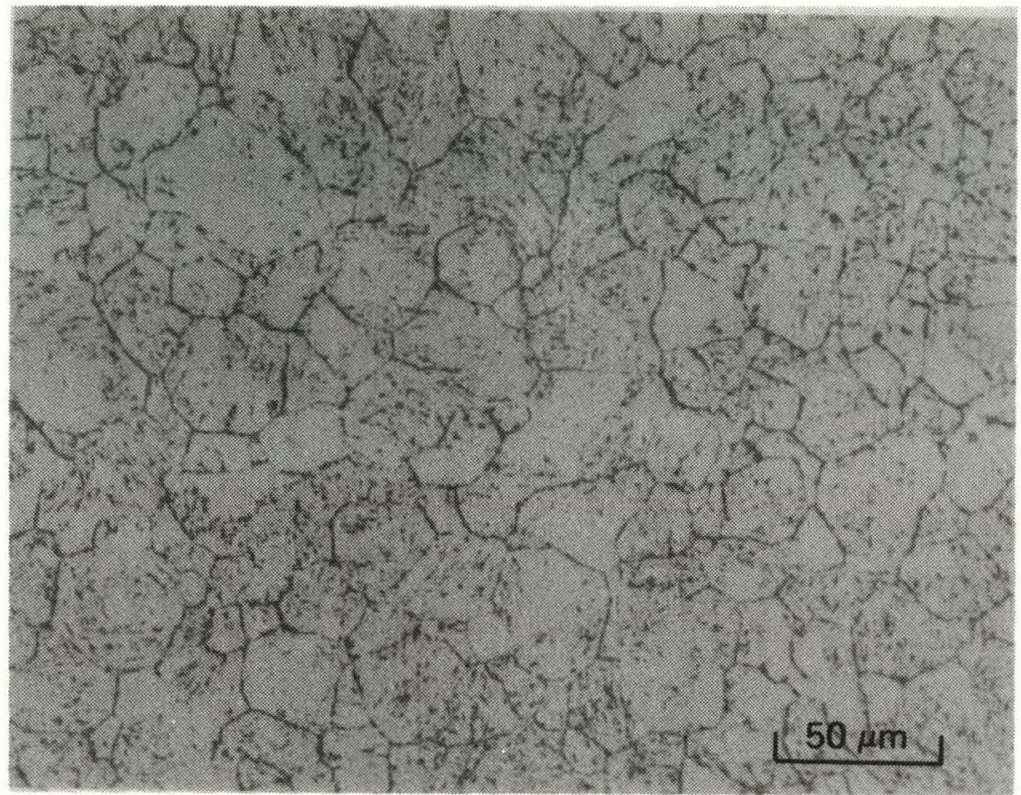

Figure 6. Typical prior austenite grain strucure of HP9-4-20.

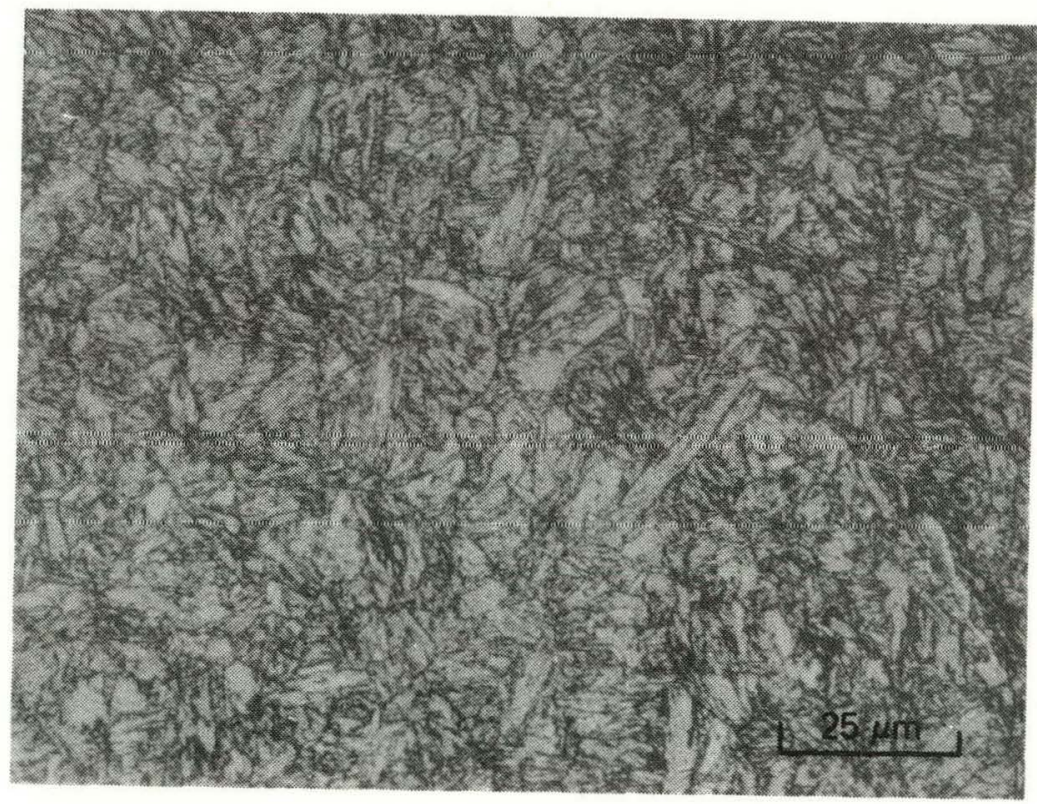

Figure 7. Microstructures of HP9-4-20 steel, etched to show martensite 1ath morphology. 


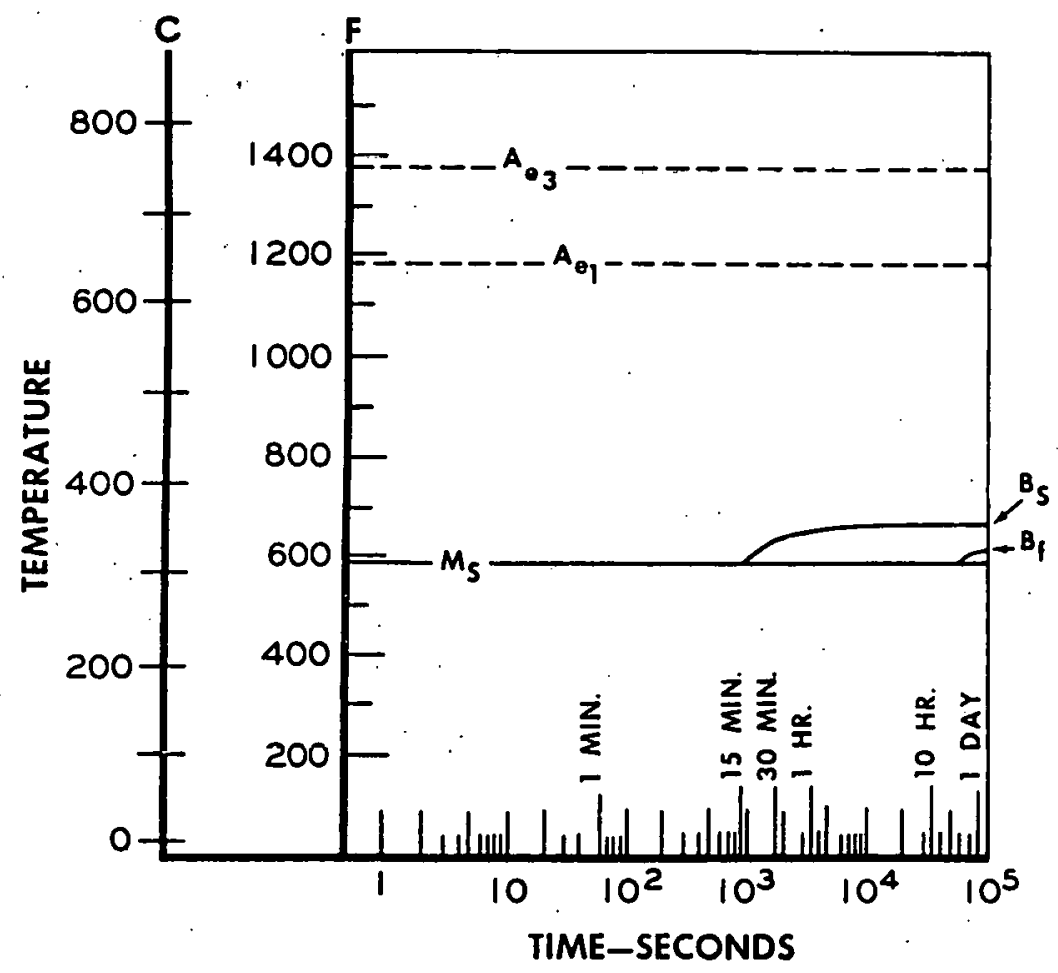

Figure 8. I sothermal transformation diagram for HP9-4-20, steel. (Ref. 3).

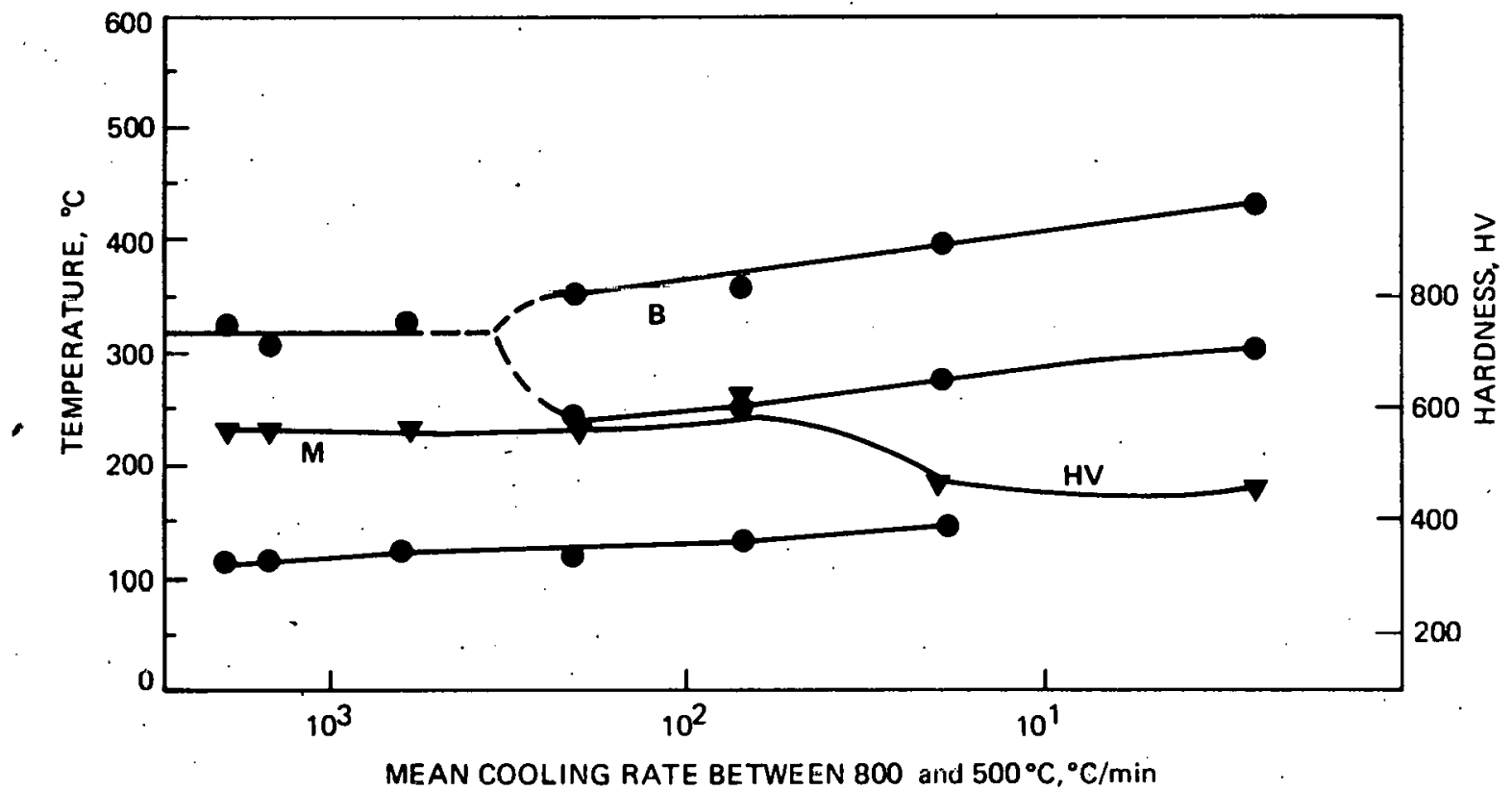

Figure 9. Continuous cooling transformation diagram for HP9-4-20 steel. (Ref. 4). 
UNLIMITED RELEASE

\section{INITIAL OISTRIBUTION}

P. R. Landon, LLNL, L-351

R. A. Woelffer, LLNL, L-125

D. W. Short, LLNL, L-217

H. Weiss, LLNL, L-217

L. R. Chapman, $Y-12$

P. A. Evans, $Y-12$

K. Helle, $Y=12$

A. H. Hunter, $\mathrm{Y}-12$

J. Koger, $Y-12$

M. Morrow, $Y-12$

T. M. Mustaleski, $Y-12$

R. E. Oakes, Jr., Y-12

B. L. Wilkinson, $Y-12$

C. C. King, R.F.

R. L. Page, R.F.

R. Krenzer, R.F.

M. J. Davis, 5830

R. J. Salzbrenner, 5832

J. L. Jellison, 5833

R. G. Henning, 5833

G. A. Knorovsky, 5833

T. B. Cook, 8000; Attn: D. M. 01 son, 8100

A. N. Blackwell, 8200

L. Gutierrez, 8400

R. J. Gallagher, 8124

D: Hartley, 8500

D. M. Bel1, 8124

J. L. Wirth, 8150 Attn: L. Hiles, 8151

G. N. Beeler, 8152

D. A. Clarin, 8152

R. D. Monson, 8152

D. B. Nel son, 8152

G. C. Story, 8152

B. F. Murphey, 8300; Attn: R. L.-Rinne, 8320

G. W. Anderson, 8330

D. M. Schuster, 8310

W. Baver, 8340

D. C. Beard, 8312

W. M. Garrison, 8312

V. Ham, 8312

T. F. Kl innowicz, 8312 (10)

M. W. Mote, 8312

D. A. Nissen, 8312

J. E. Smugeresky, 8312

R. W. Mar, 8313; Attri: D. R. Boehme

J. M. Hyzak, 8314 
J. C. Lippold, 8314 (10)

N. R. Moody, 8314

B. C. Odegard, 8314

A. J. West, 8314

L. A. West, 8315

J. A. Brooks, 8316

F. A. Greulich, 8316

J. C. Swearengen, 8316

D. E. Gregson, 8440; Attn:

J. Bolen, 8445

D. Putz, 8445

D. B. Dawson, 8453

W. R. Hoover, 8442

H. Hanser, 8445

Publications Division, 8265, for TIC (2)

Publications Division, 8265/Technical Library Processes Division, 3141 Technical Library Processes Division, 3141 (3)

M. A. Pound, 8214, for Central Technical File (3) 


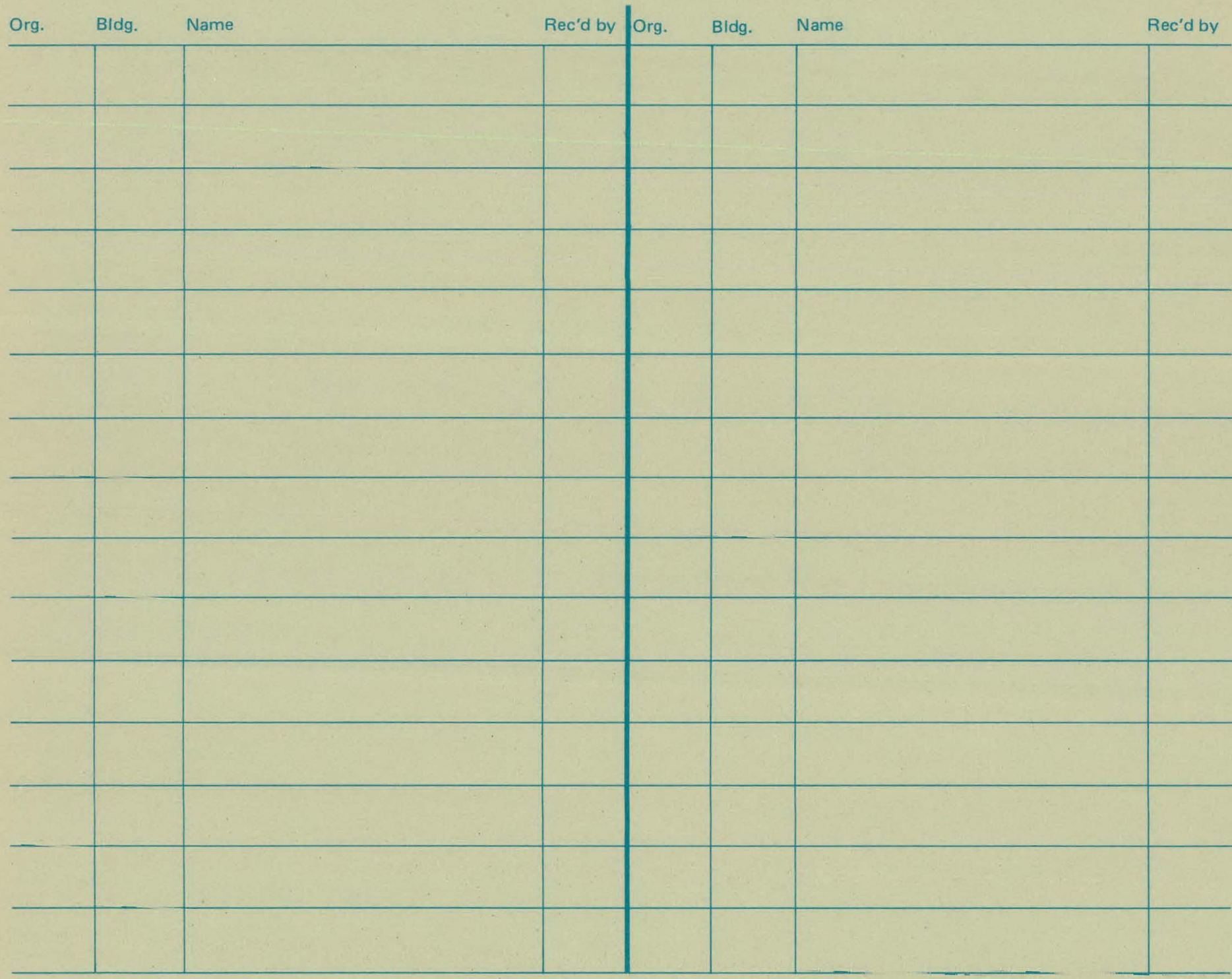

